\title{
PEMANFAATAN INTERNET SEBAGAI MEDIA INFORMASI DALAM KEGIATAN BELAJAR MENGAJAR PADA MATA KULIAH PENDIDIKAN PANCASILA
}

\author{
Sari Mellina Tobing \\ IKIP Budi Utomo Malang \\ Email: mellynanya@gmail.com
}

\begin{abstract}
This study aims to find out about the use of the internet as an information medium in teaching and learning activities in the Pancasila education course. This study uses methods that are sourced from books or commonly referred to as literature. Data collection techniques used are identification of discourse from books, papers, articles, journals, magazines, web (internet) or other information. The approach used uses a qualitative approach to content analysis. Based on the results of research on the use of the internet as a medium of information in learning activities teaching in the Pancasila Education course is able to improve the teaching and learning process for both students and educators. Because internet media is easier to access and understand so learning becomes more innovative, modern and fast. In addition to this knowledge, the Pancasila course also emphasizes awareness of the existence of moral and ethical values. This awareness cannot just be transferred through information media but also must be through face-to-face discussion.
\end{abstract}

Keywords: Use of the Internet, media information, teaching and learning 


\begin{abstract}
Abstrak
Penelitian ini bertujuan untuk mengetahui tentang pemanfaatan internet sebagai media informasi dalam kegiatan belajar mengajar pada mata kuliah pendidikan pancasila. Penelitian ini menggunakan metodeyang bersumber dari buku atau yang biasa disebut kepustakaan. Teknik pengumpulan data yang digunakan adalah identifikasi wacana dari buku-buku, makalah, artikel, jurnal,majalah, web (internet) ataupun informasi lainnya.Pendekatan yang digunakan menggunakan pendekatan kualitatif dengan analisis konten.Berdasarkan hasil penelitian pemanfaatan internet sebagai media informasi dalam kegiatan belajar mengajar pada mata kuliah Pendidikan Pancasila adalah dapat meningkatkan proses belajar mengajar baik mahasiswa maupun tenaga pendidik. Dikarenakan media internet lebih mudah untuk di akses dan di mengerti sehingga belajar menjadi lebih inovatif, modern dan cepat.Selain pengetahuan tersebut, dalam mata kuliah Pancasila juga menekankan kesadaran akan adanya nilai moral dan etika. Kesadaran ini tidak dapat sekedar ditransfer melalui media informasi tetapi juga harus melalui diskusi tatap muka.
\end{abstract}

Kata Kunci: Pemanfaatan Internet, Media Informasi, Belajar Mengajar 


\section{A. Pendahuluan}

Pada saat ini perkembangan ilmu pengetahuan dan teknologi semakin memudahkan manusia mendapatkan informasi dalam kehidupan sehari hari. Perkembangan tersebut harus di dorong dengan melakukan upaya-upaya konkrit contohnya pembaharuan dan pemanfaatan hasil-hasil teknologi dalam proses belajar mengajar yang sesuai dengan tuntutan zaman. Tidak hanya tenaga pendidik saja yang dituntut untuk bisa menggunakan internet namun para terdidik juga harus bisa mengakses media informasi yang berkaitan dengan pengetahuan.

Perubahan dari perpustakaan,buku-buku maupun media cetak yang lain menjadikan internet sebagai media sumber mencari informasi yang mudah dan up to date.

Semakin sadarnya orang akan teknologi yang dapat membantu pembelajaran sudah dapat dirasakan. Pengelolaan alat bantu pembelajaran sudah sangat dibutuhkan. Metamorphosis atau perubahan dari perpustakaan yang menekankan pada penyediaan permintaan dan pemberian layanan secara cepat dari beragamnya kemampuan individu untuk menyerap informasi, menjadikan pelayanan yang diberikan harus bervariatif dan secara luas. Selain itu, dengan meluasnya kemajuan dibidang komunikasi dan teknologi serta banyak bermunculan dinamika proses pembelajaran, maka pelaksanaan kegiatan pendidikan dan pengajaran semakin menuntut dan memperoleh media pendidikan yang bervariasi pula. Internet merupakan salah satu media yang paling dicari, paling mudah di akses, dan paling mudah dalam mencari informasi apapun termasuk informasi pembelajaran. Dengan adanya internet sangat membawa perubahan yang begitu besar dalam berbagai bidang kehidupan. Tidak perlu menunggu lama jika ingin mencari informasi di internet karena Pencarian informasi dari berbagai sumber dalam waktu singkat sangat membantu bagi masyarakat secara umum. Menurut Handayani,2012 bahwasanya Internet sdapat di katakan seperti perpustakaan raksasa. Dengan biaya yang sangat terjangkau membuat semua kalangan masyarakat dapat mengakses internet hingga ke berbagai daerah bahkan dari berbagai negara. Contoh aplikasi yang dapat digunakan adalah surel (email), media sosial (social media), dan aplikasi lainnya, contohnya seperti twitter, WhattsApp dan sebagainya.

Jumlah pengguna internet sangat banyak, mereka lebih senang menghabiskan waktu di depan internet daripada melihat acara televisi maupun 
membaca media elektronik. Banyaknya bermunculan situs-situs maupun aplikasi tentang pembelajaran membuat pengguna internet yang sebagaian besarkalangan pelajar, menjadi lebih mudah dalam mencari sumber maupun informasi yang berkaitan dengan tugas sekolah, memperdalam pengetahuan tentang berbagai topik, dapat mengembangkan skill/ ketrampilan maupun bakat tertentu dan lain sebagainya. Mereka dapat dengan mudah mengakses internet sebagai sumber belajar dari berbagai referensi, tidak hanya sebagai sumber belajar saja melainkan dapat berfungsi sebagai alat komunikasi dan hiburan sehingga ada waktu luang untuk mereka dalam menggunakan internet yang baik. Dulu sumber belajar alternatif bagi mahasiswa adalah buku/ hand book, maupun perpustakaan. Namun seiring berkembangnya zaman internet adalah alat yang paling sering digunakan untuk membantu mahasiswa dalam berbagai tugas di kampusnya. Mereka dapat mengakses dari mana saja, bisa dengan duduk-duduk di cafe bersama temanteman, menunggu antrian dengan melihatlihat internet dan sebagainya. Sehingga tidak ada patokan waktu maupun tempat agar mahasiswa dapat menggunakan internet.Internet merupakan sumber belajar utama bagi mahasiswa karena di rasa cepat,mudah,efektif dan nyaman. Internet tidak bisa menggantikan peran pendidik, tetapi internet hanya berfungsi melengkapi saja. Mahasiswa pada saat ini dituntut mandiri dan aktif dalam mencari berbagai sumber untuk tugas-tugas kuliahnya dan juga menambah wawasan pengetahuannya. Untuk mempermudah mahasiswa dalam mengakses internet diperlukan fasilitas yang mendukung, yakni layanan wifi yang disedikan di kampus dan juga tempattempat lainnya sehingga mereka dengan mudah dapat tersambung di internet baik melalui handphone maupun laptop.

\section{B. Metode}

Penelitian ini menggunakan penelitian kepustakaan (Library Research) yaitu langkah pertama mencatat semua temuan mengenai manfaat internet bagi mahasiswa pada setiap pembahasan penelitian yang di dapatkan dalam literatur-literatur maupun sumber-sumber, dan atau penemuan terbaru mengenai perilaku mahasiswa terhadap manfaat internet dalam kegiatan belajar mengajar. Setelah mencatat, langkah kedua adalah memadukan segala temuan, baik teori atau temuan baru pada pemanfaatan internet dalam mata kuliah pendidikan pancasila.Langkah ketiga adalah menganalisis segala temuan dari berbagai 
bacaan, berkaitan dengan kekurangan tiap sumber, kelebihan atau hubungan masingmasing tentang wacana yang dibahas di dalamnya. Dan Langkah terakhir adalah mengkritisi, memberikan gagasan kritis dalam hasil penelitian terhadap wacanawacana sebelumnya dengan menghadirkan temuan baru dalam mengkolaborasikan pemikiran-pemikiran yang berbeda.

\section{Teknik Pengumpulan Data}

Teknik pengumpulan data menggunakan identifikasi wacana dari berbagai sumber, utamanya dari bukubuku, makalah atau artikel, majalah,jurnal,web (internet), ataupun informasi lainnya yang berhubungan dengan artikel ini.

\section{Variabel Penelitian}

Dalam penelitian, seorang peneliti menggunakan istilah yang khusus untukmenggambarkan secara tepat fenomena apa yang hendak diteliti. Agar konsep-konsep dapat diteliti secara empiris, maka harusdi operasionalkan dengan mengubahnya menjadi variabel yang mengandung arti sesuatu yang mampunyai nilai variasi (Sofian Effendi,1989:41-42).Menurut Sumardi Suryabrata variabel dapat diartikan bermacam-macam. Variabeljuga dapat diartikan segala sesuatu yang akan menjadi objek pengamatanpenelitian
(Suryabrata,1983:72).Berdasarkan pendapat diatas maka variabel penelitian adalah suatu gejala yangmenjadi objek atau perhatian dalam sebuah penelitian. Variabel yang digunakandalam penelitian ini adalah variabel tunggal yaitu pemanfaatan internet sebagai media informasi.

\section{Pembahasan dan Hasil}

Peningkatan kualitas pendidikan di perguruan tinggi dapat ditempuh melalui berbagai cara, di antaranya peningkatan kompetensi dosen, peningkatan muatan kurikulum, peningkatan kualitas pembelajaran dan penilaian hasil belajar, peningkatan bekal ketrampilan mahasiswa, penyediaan bahan ajar yang memadai, dan penyediaan sarana belajar. Ketersediaan bahan ajar dan sarana belajar merupakan faktor penting dalam menunjang keberhasilan proses pembelajaran. Namun demikian sering kali bahan ajar Pendidikan Pancasila yang ada di perpustakaan tidak mampu memenuhi kebutuhan belajar mahasiswa, sehingga perlu memanfaatkan sumber belajar yang lebih baik. Salah satu sumber belajar yang dapat digunakan oleh mahasiswa secara mandiri adalah jaringan internet. Untuk itu, bekal ketrampilan mahasiswa khususnya dalam memanfaatkan teknologi internet sangat diperlukan. Melalui internet, mahasiswa 
dapat mengakses berbagai informasi dan ilmu pengetahuan sesuai kebutuhan yang relevan dengan subjek mata kuliah. Sehingga pemanfaatan jaringan internet sebagai sumber belajar, akan membantu mempermudah dan mempercepat penyelesaian tugas-tugas perkuliahan, termasuk penyelesaian tugas akhir. Oleh karena itu, dosen sebagai motivator dan dinamisator dalam pembelajaran hendaknya memberi dorongan serta menciptakan kondisi agar mahasiswa dapat secara aktif menemukan ilmu pengetahuan baru melalui pemanfaatan teknologi internet. Materi Pendidikan Pancasila lebih sering menggunakan metode ceramah namun hal itu sangat membosankan dan bersifat konvensional.

Internet saat ini sebagai suatu kebutuhan yang mutlak, maka kehadiran internet pada dasarnya sangat membantu dunia pendidikan untuk mengembangkan situasi belajar mengajar yang lebih kondusif dan interaktif. Dimana para peserta didik tidak lagi dihadapkan dengan situasi yang lebih konvensional, namun mereka akan sangat terbantu dengan adanya metode pembelajaran yang lebih menekankan pada aspek pemakaian lingkungan sebagai sarana belajar. Semua jenis pembelajaran menggunakan jasa internet, tak terkecuali mata kuliah pendidikan pancasila, dimana mahasiswa lebih dominan merasa bosan dan pasif jika dihadapkan dengan mata kuliah ini. Oleh karena itu media pembelajaran pendidikan pancasila tidak hanya ceramah dan diskusi saja namun dapat menggunakan media yang lain yaitu internet. Dengan adanya media internet pembelajaran pendidikan pancasila lebih efektif.

Gambar.1 Kedudukan media dalam sistem pembelajaran Pendidikan Pancasila

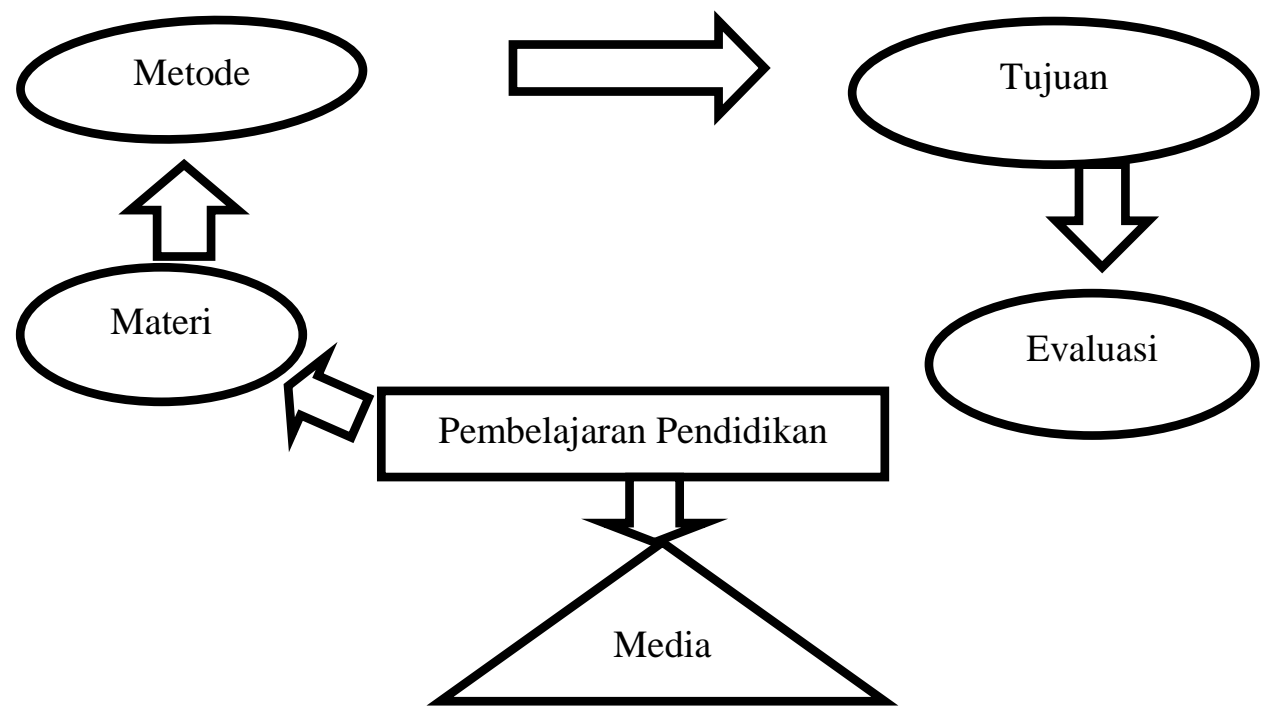


Media tidak terlepas dari perkembangan teknologi pendidikan, dalam hal ini pendidikan pancasila. Media pembelajaran sama halnya dengan audiovisual, sebagai alat komunikasi, bagian integral dalam sistem pembelajaran, dan juga sebagai salah satu sumber yang dapat dikembangkan maupun dimanfaatkan guna keperluan belajar.

Berikut manfaat internet dari berbagai sumber antara lain:

1. Menambah wawasan

Internet menyediakan informasi yang hampir tidak terbatas.Beragam artikel telah tersedia di dalamnya sehingga mudah diserap danmenambah wawasan bagi para peserta didik yang mengaksesnya.

2. Memicu ide dan gagasan

Internet memberikan informasi yang dapat dicari denganmudah, cukup mengetikkan kata kunci pada mein pencari, anekainformasi terkait pun muncul dan mampu memicu ide sertagagasan bagi peserta didik.

\section{Sebagai sumber data dan referensi}

Mencari data maupun informasi dapat dengan mudah apalagi ditambah dengan situs maupun data yang kredibel.

Media Internet juga memiliki dampak negatif apabila digunakan dengan tidak baik. salah satu di antaranya adalah sebagai berikut :
1. Pornografi, banyak yang menganggap bahwa internet identik dengan pornografi. Hal ini benar adanya karena terdapat homepage atau situs yang berisikan content khusus dewasa, artinya bahwa dengan kemudahan iniseseorang akan dengan mudah mengakses hal-hal yang berbau porno.namun sekarang sudah mulai dibatasi dan ada peraturan tertulis tentang uu pornografi di internet.

2. Prestasi Belajar menurun apabila menggunakan internet terlalu sering terkadang para pelajar terlalu termasuk waktu belajar yang menyebabkan nilai dan prestasi mereka dapat menurun.

3. Mengganggu Kesehatan, gangguan kesehatan yang paling dirasakan adalah mata, selain itu lupa waktu makan, istirahat dan mengerjakan aktivitas yang lain.

4. Mengabaikan kehidupan sosial. Adakalanya seseorang yang telah kecanduan internet cukup pasif bahkan tidak menghiraukan lingkungan sekitar. Karena terlalu asyik dengan dunia maya.

5. Kecanduan internet, internet bisa menyebabkan ketergantungan (hal ini biasa terjadiketika seseorang 
telah sangat suka terhadap jejaring social ataupun gameonline ) hingga mengakibatkan lupa waktu dalam kehidupannya.

6. Information overload, karena menemukan informasi yang tak habishabisnya yang tersedia diinternet, sejumlah orang rela menghabiskan waktu berjam-jam

untuk mengumpulkan dan mengorganisir berbagai informasi yang ada.

7. Cyber-relational addiction, adalah keterlibatan yang berlebihan pada hubungan yang terjalin melaluiinternet (seperti melalui chat room dan virtual affairs) sampai kehilangan kontak dengan hubungan-hubungan yang ada dalam dunia nyata.Jadi, internet menimbulkan manfaat yang tiada batas bagi penggunanya, meskipun dalam kenyataan masih terdapat penyalahgunaan internet yang dapat membawa pengaruh negatif .

Lalu bagaimanakah agar media internet bisa berdampak positif terhadap peserta didik, karena untuk menyelesaikan tugas perkuliahan sudah pasti internet merupakan bahan informasi maupunsebagai referensi yang sangat lengkap baik perpustakaan berjalan dan selalu memnberikan informasi secara up to date. Apa yang dibutuhkan para peserta didik dalam mencari materi tentang pendidikan Pancasila telah tersedia di internet.

Menurut berbagai sumber referensi manfaat internet terhadap pembelajaran di kutip dari buku karya Dr.Rusman, M.Pd yang berjudul Belajar dan Pembelajaran: Berorientasi Standar Proses Pendidikan yakni secara tidak langsung internet mendorong dunia pendidikan agar dapat menyesuaikan dengan arus informasi globalisasi sedangkan secara langsung internet dapat dimanfaatkan dengan baik sebagai sumber dan media pembelajaran pada peserta didik untuk mengembangkan ilmu pengetahuan.Program E-Learning CBI dapat menjadi penyeimbang kedua hal tersebut.

Menururt Sudirman Siahaan (www.Depdiknas.go.id/internet/html) ada tiga bentuk agar internet dapat dijadikan sebagai dasar dalam pengembangan sistem pembelajaran yakni:

1. Internet sebagai Suplemen (tambahan), bersifat optional artinya para peserta didik dapat dengan bebas memilih apakah akan memanfaatkan materi pembelajaran di internet atau tidak, dikarenakan tidak ada kewajiban/ keharusan dalam mengakses materi pembelajaran. 
2. Komplemen (Pelengkap), tujuannya untuk membantu peserta didik apabila mengalami kesulitan dalam materi pelajaran, sehingga dapat mempermudah mereka dalam menguasai atau memahami materi yang diberikan oleh pendidik.

3. Subtitusi (Perngganti), peserta didik tidak perlu bertatap muka dengan pendidik karena bentuk pembelajaran seperti bahan belajar, diskusi konsultasi, latihan soal maupun ujian sepenuhnya dilakukan melalui e-mail, chat room, buletin board,maupun online conference dan lain-lain.

Dengan memanfaatkan teknologi modern yakni penguasaan internet diharapkan dapat membantu para peserta didik dalam menguasai bahan maupun materi pembelajaran Pendidikan Pancasila.

\section{Simpulan}

Dari berbagai sumber menyebutkan bahwa internet merupakan sumber informasi yang memiliki peran penting dalam menunjang kegiatan belajar mengajar dalam hal ini materi pembelajaran pendidikan pancasila, dan juga sebagai media informasi yang tidak terbatas baik ruang dan waktu, sehingga para peserta didik dapat mengakses internet diluar jam belajar. Materi pendidikan pancasila sangat banyak dan beragam sehingga agar lebih memudahkan para peserta didik belajar tidak hanya melalui ceramah dan diskusi saja melainkan dapat menambah informasi maupun pengetahuan yang berkaitan dengan tugas-tugas materi pembelajaran pancasila dengan mengakses internet. Tak lupa pula media internet akan berjalan dengan baik apabila mendapat dukungan dari berbagai elemen yang ada dalam penyelenggaraan pembelajaran pendidikan pancasila. Media internet mempunyai dampak negatif maupun positif ,sehingga baik pengajar maupun peserta didik harus dapat memilah agar pembelajaran dapat berjalan dengan optimal.Oleh karena itu harus ada kerjasama dan dukungan dari keduanya.

\section{Daftar Pustaka}

Isdhana, Farrah, (2011). Pemanfaatan Internet Sebagai Sumber Belajar Mahasiswa Prodi PPKn FIS UNNES. Semarang : Fakultas Ilmu Sosial Universitas Negeri Semarang,2011

Jalinus Nizwardi Dr,Ambiyar Dr,(2016), Media dan sumber pembelajaran,Jakarta; kencana.

Munir, (2009). Pembelajaran Jarak Jauh Berbasis Teknologi Informasi dan Komunikasi. Bandung: Alfabeta. 
Warsita, Bambang, (2008). Teknologi Pembelajaran. Jakarta: Rineka Cipta.

Murdiono Mukhamad. 2010. Pelatihan Penggunaan Internet Sebagai Media Penelusuran Sumber Pustaka Bagi Guru-Guru Pendidikan Kewarganegaraan Se-Kota Yogyakarta. Jurnal Inotek LPM.UNY. Vol 14 No 1 https://journal.uny.ac.id/index.ph p/inotek/article/view/2283/1887 (diakses 20 Maret 2019

Rusman Dr,M.Pd, (2017),Belajar dan Pembelajaran Berorientasi Standar Proses Pendidikan, Jakarta;Kencana 